\title{
STRUCTURED ASSESSMENT OF VIOLENCE RISK IN YOUTH IN CLINICAL PRACTICE
}

\author{
Jelena Kostić1,2, Aleksandra Stojanović2 , Miodrag Stanković1,2, Olivera Žikić1,2
}

\begin{abstract}
Violence risk assessment in adolescents is an emergent research area with great potential for clinical application. The need for standardization of clinical approaches has led to the development of structured professional judgment tools for violence risk assessment in youth. The aim of the study was to present a structured evaluation of violence risk assessment in clinical work with two male patients aged 12 and 17 with a psychiatric diagnosis of conduct disorder, socialized type and acute psychotic disorder. The Structured Assessment of Violence Risk in Youth (SAVRY) was used in the assessment to help estimate the patients' risk for future violence. Based on the systematic analysis and consideration of the SAVRY Historical, SocioContextual and Individual risk factors balanced against the Protective factors, both patients were rated as being at high risk for future violence. In order to control and reduce the risk of further violent behaviour, an intervention plan was designed. With the increasing recognition of the public health importance of violence, the violence risk assessment is the subject of considerable clinical and research interest. In this way, we are joining the global trend of opposing the social pathological emergence of violence among youth and violence in general.
\end{abstract} Acta Medica Medianae 2021;60(3):56-60.

Key words: violence, violence risk assessment, youth

\begin{abstract}
${ }^{1}$ University of Niš, Faculty of Medicine, Department of Psychiatry, Niš, Serbia

University Clinical Center Niš, Centre for Mental Health Protection, Niš, Serbia
\end{abstract}

Contact: Jelena Kostić

12b/53 Branko Krsmanović St., 18000 Niš, Serbia

E-mail: jelenakostic73@gmail.com

\section{Introduction}

Youth violence is widely recognized as a serious and complex public health problem. The terms violence and aggression are often used as synonyms. However, not every aggression is violence, whereas every violence implies aggression. By violence we understand any behavior intended to do extreme physical harm, such as injury or death, to another person who does not want to be harmed (1).

Mental health professionals are regularly called upon to assess the violence risk among children and adolescents. Violence risk assessment is a complex and responsible task which involves the identification and study of hazards in order to reduce the possibility of its occurrence. The assessment of risk for youth violence used to largely rely on clinical observations and unstructured clinical assessment. However, research has identified unstructured clinical violence risk assessments to be prone to human error, subjectively biased, and of poor predictive accuracy (2). Structured professional judgment tools are typically designed to help clinicians focus on preventing or managing, rather than predicting, the occurrence of future violence through the integration of dynamic risk factors that might indicate a reduction or increase in the stability of one's risk (3).

The Structured Assessment of Violence Risk in Youth (SAVRY) (4) is a violence risk assessment instrument modeled after a measure normed on adults (i.e., HCR-20), but consisting of items associated with risk for future violence in adolescents. The SAVRY was designed to provide clinicians with a structured method of examining the important risk and protective factors to allow for a professional judgment of a youth's risk for future violence. The SAVRY consists of 24 risk factors and 6 protective factors that have a demonstrated relationship with future violent behavior. Items are divided into four domains: Historical, Social/Contextual and Individual/Clinical risk Factors and Protective Factors. Historical risk factors refer to past behaviour or experiences that are usually static and unchangeable, such as prior episodes of violence. Historical risk factors for violence include a history of violence, history of nonviolent offending, early initiation of violence, past supervision/interventions failures, 
history of self-harm or suicide attempts, exposure to violence in the home, childhood history of maltreatment, early caregiver disruption, parental/caregiver criminality and poor school achievement. Social/ contextual risk factors consider the influence of interpersonal relationships (peer, family), connection to social institutions and the environment like peer rejection and delinquency, stress and poor coping, lack of personal/social support, poor parental management and community disorganization (4). Individual risk factors are those factors that concentrate on a youth's attitudes and behaviours and include risk taking/impulsivity, substance use difficulties, anger management problems, low empathy/remorse, attention deficit/hyperactivity difficulties, poor compliance and low interest/commitment to school. Each risk factor is rated on a three-level scale (low, moderate, or high). SAVRY also includes an assessment of protective factors as variables that potentially decrease the likelihood of violence. Protective factors include prosocial involvement, strong social support, strong attachments and bonds, positive attitude toward interventions and authority and resilient personality traits (4). The final SAVRY risk rating (low, moderate, or high) represents a structured judgment of the risk for future violence. Although the final risk ratings are not linked to specific scores or base rates in the population, empirical studies often find a linear relationship between the number of risk factors and violence risk (5).

The aim of this study was to show a structured way to evaluate violence risk assessment in the clinical work with two male patients, aged 12 and 17. Structured Assessment of Violence Risk in Youth (SAVRY) was used in the assessment to help estimate the patients' risk for future violence. Based on the structured assessment of violence, a plan for intervention and management decisions was designed in order to control and lower the possibility of future violent behavior. Information used to rate the SAVRY items included a youth self report, parental/caregivers report, the social worker's report, school records, and a psychological and psychiatric report.

A male patient aged 12, was diagnosed with conduct disorder, socialized type. Dominant behaviour included intimidation and threats to others, frequent initiation of fights, use of weapons causing serious physical harm to another person, physical cruelty to others, fraud and theft while confronting the victims. He was included in youth groups who demonstrated antisocial and delinquent activities. Behavioral problems started to appear in an early age in the form of provocative and defiant behavior in the family and social environment. He smoked marijuana occasionally, when he was with friends. He lived in a multi-member, socially and economically marginalized family with parents and brothers; relations between the family members were tense and full of conflicts. Parents did not have adequate control and monitoring over their child's behavior. The relationship between the parents was disturbed by frequent conflicts and separation, with suspected partner violence. The father exhibited antisocial activities and was legally punished for criminogenic behavior. During the interview, the patient did not verbalize the feeling of guilt or shame in relation to the consequences of his actions. There was an individual low threshold of frustration tolerance and impaired impulse control. Earlier attempts to involve the patient in psychological-psychiatric monitoring were discontinued and without success.

A male patient aged 17 physically attacked his father inflicting him with the fracture of two ribs which was medically attended. Due to violent behaviour, he was separated from his family and placed in a social institution, where he physically injured another resident. Available data indicated that the adolescent exhibited aggressive behavior in the family and among peers since the age of 13 with frequent episodes of alcohol and marijuana abuse and poor school results and connection to school. He had no close peer relationships, was expelled from high school and dropped out of school due to a large number of absences. He lived in a broken family, with his father and younger sister, the parents were divorced. Both parents were treated for addiction at the regional centre for mental health center. Psychotic symptoms were evidenced at examination.

\section{Discussion}

Based on the systematic appraisal and consideration of the SAVRY Historical, Socio-Contextual and Individual risk factors balanced against the Protective factors domain, the patient from the first case presentation was rated as being at a high risk for future serious violence. History of violence, history of nonviolent offending, early onset of violence, past treatment failures, poor school achievement and parental criminality as well as exposure to violence at home were coded at a High level of severity. One of the most consistent findings of longitudinal research conducted over the past 50 years has been that early aggressive behavior predicts later aggressive, antisocial, violent, and criminal behavior (6).

Social/Contextual risk factors evident in this case at being at High risk for serious future violence include Peer Delinquency, Poor Parental Management and Lack of Social Support. Affiliations with delinquent peers are a risk factor for subsequent violence, as well as for overt and concealed forms of delinquency (7). Furthermore, research has found that coming from a family that experienced divorce, child maltreatment, domestic violence, being on welfare, having a mother who is young or unemployed or having a father with behavioral problems all increase the likelihood of young men committing violent acts (8). In addition, it has been stated that an antisocial personality disorder in parents is the best predictor for the development of behavioral disorders in children (9). The following Individual/Clinical risk factors were identified as High - Negative Attitudes, Poor Compliance, SubstanceUse Difficulties and Low Interest/Commitment to School. Summary consideration of SAVRY Risk factors indicates that the patient's risk for future 
violence is high. There was a notable absence of protective factors, as assessed by SAVRY.

Returning to school and engaging in prosocial activities without interventions and a plan was not recommended. Working with the patient required multisystemic intervention strategies - treatment programs that integrate a variety of interventions. If risk factors can be mitigated through circumstance of intervention, patient risk may be reduced (5). Cognitive-behavioral interventions, problem solving skills training and anger management were applied, together with family-based interventions including parent management training, peer intervention strategies with a focus on peer selection and resisting peer influence as well as school interventions as response to the broad range of individual and social/ contextual risk factors that have been shown to contribute to violent behavior.

In the case of the other patient, we coded the following SAVRY Historical risk factors at a high level of severity: History of Nonviolent Offending, Early Caregiver Disruption and Poor School Achievement. Early caregiver disruption most commonly indicates the caregivers' inability to provide love, safety, support, food and/or basic needs for the child. Although caregivers' disruption and childhood history of maltreatment may often overlap, this item is not considered synonymous with neglect and abuse (4). Among Social/Contextual risk factors, Peer Rejection, Poor Parental Management and Lack of Social Support were at high risk. In the category of Individual/Clinical risk factors, including those indicating difficulties in generating non-aggressive problem solving, alcohol and substance abuse, and low interest in school, the patient was assessed as having a high risk for further violence. Psychosis was identified as a significant additional risk factor for violence (irritability, aggression and violence were highly expressed during a psychotic episode). Certain psychotic symptoms, such as delusions and command hallucinations, particularly when accompanied by anger or stress, can elevate the risk for violence (10). Among individuals with mental disorders, the risk of them being violent is also increased by substance abuse (11). The present protective factor was the positive attitude of the patient towards the interventions. A review of the SAVRY risk factors against protective factors indicates that the patient's risk for future violence is high.

A medical follow-up is important to ensure that acute psychosis is being adequately treated. The patient would benefit from substance abuse treatment in the community, skills training on issues of assertiveness, problem solving skills training, as well as educational and family support.

\section{Conclusion}

Violence risk assessment in adolescents is an emergent research area with great potential for clinical application. Upon applying the Structured Assessment of Violence Risk in Youth - SAVRY, the patients in these cases illustrate overall high risk of future violent behavior. The patients required different interventions. With the increasing recognition of the public health importance of violence, the violence risk assessment is the subject of considerable clinical and research interest. In this way, we are joining the global trend of opposing the social pathological emergence of violence among youth and violence in general. 


\section{References}

1. Bushman BJ, Huesmann LR. Aggression. In Fiske ST, Gilbert DT, Lindzey G, editors. Handbook of social psychology. New York: John Wiley \& Sons, 2010. p. 833-63. [CrossRef]

2. Monahan J. The clinical prediction of violent behavior. (DHHS Publication No. ADM 89-92). Rockville, MD: National Institute of Mental Health; 1981.

3. Vincent GM. Psychopathy and violence risk assessment in youth. Child Adolesc Psychiatr Clin N Am 2006;15:407-28. [CrossRef] [PubMed]

4. Borum $R$, Bartel $P$, Forth $A$. Manual for the Structured Assessment for Violence Risk in Youth (SAVRY), Version 1.1. Tampa, FL: University of South Florida; 2003.

5. Borum R, Lodewijks $H$, Bartel $P$, Forth $A$. Structured Assessment of Violence Risk in Youth. In Otto RK, Douglas KS, editors. Handbook of violence risk assessment. New York: Routledge, 2010. p. 63-80.

6. Dubow EF, Huesmann LR, Boxer P, Smith C. Childhood and adolescent risk and protective factors for violence in adulthood. J Crim Justice 2016;45:26-31. [CrossRef] [PubMed]
7. Kenan K, Loeber R, Zhang Q, Stouthamer-Loeber M. The influence of deviant peers on the development of boys disruptive and delinquent behavior: a temporal analysis. Dev Psychopathol 1995;7(4):715-26.

[CrossRef]

8. DeLisi M, Piquero AR, Cardwell SM. The unpredictability of murder: Juvenile homicide in the pathways to desistance study. Youth Violence Juv Justice 2016; 14(1):26-42. [CrossRef]

9. Murray J, Farrington DP. Risk factors for conduct disorder and delinquency: key findings from longitudinal studies. Can J Psychiatry 2010;55(10):633-42. [CrossRef] [PubMed]

10. Sariason A, Lichtenstein P, Larsson $H$, Fazel S. Triggers for violent criminality in patients with psychotic disorders. JAMA Psychiatry 2016;73(8):796-803. [CrossRef] [PubMed]

11. Silverstein SM, Del Pozzo J, Roché M., Boyle D, Miskimen T. Schizophrenia and violence: Realities and recommendations. Crime Psychol Rev 2015;1(1):2142. [CrossRef] 


\title{
STRUKTURISANA PROCENA RIZIKA OD NASILJA MLADIH U KLINIČKOJ PRAKSI
}

\author{
Jelena Kostić1,2, Aleksandra Stojanović2 , Miodrag Stanković1,2, Olivera Žikić1,2 \\ ${ }^{1}$ Univerzitet u Nišu, Medicinski fakultet, Katedra za psihijatriju, Niš, Srbija \\ 2Univerzitetski klinički centar Niš, Centar za zaštitu mentalnog zdravlja, Niš, Srbija \\ Kontakt: Jelena Kostić \\ Branko Krsmanović 12b/53, 18000 Niš, Srbija \\ E-mail: jelenakostic73@gmail.com
}

Procena rizika za nasilje je istraživačko područije sa velikim potencijalom za kliničku primenu. Potreba za standardizacijom kliničkih pristupa dovela je do razvoja strukturisanih profesionalnih instrumenata za procenu rizika nasilja mladih. Cilj rada bio je da se prikaže strukturisana procena rizika za nasilje kod dvojice bolesnika, 12 i 17 godina starosti, sa dijagnozom poremećaja ponašanja socijalizovanog tipa i akutnog psihotičnog poremećaja. Korišćena je Strukturisana procena rizika za nasilje kod mladih (engl. SAVRY).

$\mathrm{Na}$ osnovu sistematske analize i razmatranja životnih, socijalno-kontekstualnih i individualno-kliničkih faktora rizika u odnosu na protektivne faktore, procenjen je visok rizik za dalje vršenje nasilja kod bolesnika i napravljen je plan intervencija.

Sa sve većim prepoznavanjem javnog zdravstvenog značaja nasilja, procena rizika za nasilje je predmet značajnog kliničkog i istraživačkog interesa. Na ovaj način pridružujemo se globalnom trendu suprotstavljanja socijalno-patološkoj pojavi nasilja među mladima i nasilju uopšte.

$$
\text { Acta Medica Medianae 2021;60(3):56-60. }
$$

Ključne reči: nasilje, procena rizika, mladi 